Article

\title{
Environmental Corporate Social Responsibility (ECSR) on the Example of Polish Champion Oil, Gas and Mining Companies
}

\author{
Magdalena Suska (D) \\ Department of European Integration and Legal Studies, SGH Warsaw School of Economics, \\ 02-554 Warsaw, Poland; msuska@sgh.waw.pl
}

check for updates

Citation: Suska, M. Environmental Corporate Social Responsibility (ECSR) on the Example of Polish Champion Oil, Gas and Mining Companies. Sustainability 2021, 13, 6179. https://doi.org/10.3390/ su13116179

Academic Editor: Danuta Zawadzka

Received: 21 April 2021

Accepted: 27 May 2021

Published: 31 May 2021

Publisher's Note: MDPI stays neutral with regard to jurisdictional claims in published maps and institutional affiliations.

Copyright: (C) 2021 by the author. Licensee MDPI, Basel, Switzerland. This article is an open access article distributed under the terms and conditions of the Creative Commons Attribution (CC BY) license (https:/ / creativecommons.org/licenses/by/ $4.0 /)$.

\begin{abstract}
The author uses empirical research to assess the environmental practices of the Polish champion oil, gas and mining companies to show that they are involved in Environmental Corporate Social Responsibility (ECSR). This paper investigates the tools such companies apply to implement the ECSR and the actions they undertake to reduce their environmental footprint. The community and environmental impact are inherent in the business activities of such companies. The author analyses the annual integrated reports published by Polish leading oil, gas and mining companiesPKN ORLEN, PGNiG and KGHM Polska Miedź-published in 2014-2019 in terms of environmental and climate responsibility. The ECSR initiatives undertaken by these companies are analyzed with regard to four categories: (1) water and wastewater management, (2) air emissions, (3) waste management and circular economy concept, and (4) energy management. All analyzed companies identify, supervise and monitor environmental issues, apply environmentally friendly technologies and techniques to reduce emissions to the environment and the amount of waste and wastewater, enable the effective use of natural resources in order to meet the new environmental challenges in the circular economy, and participate in $\mathrm{R} \& \mathrm{D}$ projects regarding new technologies.
\end{abstract}

Keywords: ECSR; Poland; oil; gas and mining companies; environmentally friendly initiatives

\section{Introduction}

In a dynamically developing market economy, there can be observed an increased interest in the concept of the business management based on conscious activities oriented not only to financial profits but also towards good social and environmental practices. The operation of a company is, hence, a collection of actions undertaken by those who are inside and outside of it, and its sustainability highly depends on the level of the fulfilment of all stakeholders' expectations. The company's activities affect not only its owners, managers and stockholders, but also local communities and the other subjects they have a direct and indirect impact on. For decades, it has been emphasized that companies should take responsibility for all decisions and actions undertaken towards the whole group of stakeholders, such as different people, institutions and the environment, and the companies' responsibilities extend beyond traditional economic and legal obligations [1-4] (The impact of the implementation of the CSR activities on various groups of stakeholders can be quite broad. In [5], the authors distinguish between employees, the local community, clients, contractors and the natural environment). Therefore, the concept of Corporate Social Responsibility (CSR) has emerged to address the social and environmental impact of companies' operations and activities. CSR actions have an interdisciplinary character and are essential to economic, historical and cultural variables, as well as variables from areas related to management, psychology, philosophy, sociology and political sciences, which determine the companies' environment, such as, e.g., the need to protect the natural environment or put pressure on even lower production costs, which often leading to the infringement of basic human rights and freedoms [6,7]. The growing ecological aspect of the companies' development contributes to the fact that they also take into consideration the 
natural environment as a kind of a stakeholder in the implementation of the Environmental Corporate Social Responsibility (ECSR).

The social and ecological corporate responsibility is, in Poland, an initiative which is still not widely implemented. According to the study on the CSR of the largest Polish companies, only $32.1 \%$ of the researched companies have their own codes of ethics (mainly companies in the financial, oil, gas and mining industries), and only $15.4 \%$ of them issue social reports (preliminary oil, gas and mining companies). Yet about $48.3 \%$ of the companies listed on the Warsaw Stock Exchange report on social and environmental activities in their annual reports [8]. What is more, the ECSR is still not deeply rooted in the awareness of Polish entrepreneurs, especially in the sphere of SMEs and local communities. Professional tools to implement socially and ecologically responsible principles are mainly used by large enterprises (ecology is one of the most important aspects of the CSR reported by large Polish companies- $67.8 \%$ of the analyzed companies report on environmental aspects [8]. Oil, gas and mining companies are leaders in this area).

The list of the tools applied in the management of the CSR is comprehensive and closely connected to the company's organizational culture and the scope of its business activities, including social campaigns (actions to change attitudes or behaviors of a certain group of people by means of media), cause-related marketing (taking into account both the marketing aims and social needs in a company's operation), ethical programmes for employees (to integrate the employees around the common values), social reporting (to present transparently the picture of management and responsible conduct of the business activity), corporate governance, eco-marking and social marketing, reduction in emissions of waste, pollutions and greenhouse gases, socially responsible initiatives (taking into consideration the assessment criteria of the possibility of a long-term growth of the companies' value based on social and ecological performance), employees' voluntarism, as well as intersectoral cooperation (cooperation with NGOs, universities and other institutions to better fulfil common objectives due to the synergy effect).

The primary aim of this study is to analyze the tools of the ECSR implemented by Polish champion companies operating in the oil, gas and mining industries as well as to investigate the initiatives and good practices they undertake in terms of the environment and the climate. The main thesis of this study is that Polish champion oil, gas and mining companies take actions to minimize their environmental footprint. The "enclave" character of such companies, on the one hand, can limit the width of their impact, but on the other hand, create an intense local footprint, particularly when the activity is on land rather than offshore [9]. Therefore, given the potential negative impact on the natural environment, $a$ question arises as to what kind of ecologically responsible tools they use and what kind of initiatives they undertake to protect the natural environment and to minimize the negative environmental consequences of their business activities.

\section{Concept of the CSR and ECSR}

Corporate Social Responsibility (CSR) has had a long history and tradition; however, it is challenging to decide how far back into the literature to delve to start talking about the concept. Its roots can be traced in the early years of the Cold War [10]. The publication of Bowen's landmark book "Social responsibilities of the businessman" in 1953, is believed to mark the beginnings of the contemporary period of literature devoted to the concept, and the author himself is considered as the "father of CSR". Bowen formulated an initial definition of the concept, which referred to "obligations of businessmen to pursue those policies, to make those decisions, or to follow those lines of action which are desirable in terms of the objectives and values of our society" [11] (p. 6). Since the 1960s, there has been observed a proliferation of CSR; it was argued that socially responsible behavior goes beyond the pure economic interests of a business [12] and companies have not only economic and legal obligations, but also certain responsibilities to society [1,2]. It has also been emphasized that their social responsibility contains a degree of voluntarism and acceptance of certain costs, which might not bring any direct measurable economic 
returns [13]. In the 1980s, Carroll devised a four-dimensional model of CSR based on the conduct of a business so that it is economically profitable, law abiding, ethical and socially supportive [14]. Later, he depicted it in the form of a pyramid including economic, legal, ethical and philanthropic responsibilities [15,16]. In the 1990s and 2000s, companies continued their search to rationalize and legitimize the actions they took in terms of implementing socially responsible policies [17], which even accelerated in terms of its global outlook [18]. Whereas the initial research did not indicate many financial benefits obtained from socially responsible practices, further analyses implicated a positive effect of the CSR on a company's financial performance [19-22]. These findings triggered a new scope of inquiries focused not on whether CSR works, but on what induces companies to engage in socially responsible behavior. From this question, certain dimensions of CSR emerged, with one area recently receiving much attention, namely environmental corporate social responsibility. The environmental aspect of the companies' social responsibility is present in the European Commission's definition of the CSR, according to which enterprises should "integrate social, environmental, ethical, human rights and consumer concerns into their business operations and core strategy in close collaboration with their stakeholders" to maximise the stakeholders' value and identify, prevent and mitigate their potential negative impact [23].

For almost half of a century, the conservation of natural resources, the proper disposal of waste and the reduction of carbon emissions have been at the center of worldwide interest [24]. Many different environmental issues have become primary global challenges of the 21 st century [24,25]. Business organizations, after witnessing an increase in environmental disasters and catastrophes to which occurrence often contributed to unethical business interests and irresponsible human behaviors, have oriented to ecological and social responsibility. They actively seek to integrate environmental issues into their core activities by, amongst other means, promoting eco-friendly products and eco-innovations [25-29], encouraging eco-tourism [30-32] and developing environmentally friendly behavior [33,34]. These studies have laid the empirical foundations for the development of a holistic (considering positive interactions among all stakeholders) organizational context for the ECSR.

The concept of the ECSR was also researched from the perspective of corporate governance, performance and reputation [35-38] as well as consumer behavior [39,40]. However, there are relatively few environmental studies dedicated to companies operating in specific industry sectors, e.g., oil, gas and mining companies, investigating the environmental measures to protect the environment and the climate (such industries, due to the specificity of their operation, often exert a negative impact on the natural environment). Although there is a number of studies on the social and ecological aspects of the oil, gas and mining industries [41-44], they do not investigate particular companies in terms of the specific actions taken to reduce their environmental footprint.

\section{Scope and Methods of the Analysis}

The study investigates the scope of the ECSR activities undertaken by three top Polish companies in the oil, gas and mining industries listed on the stock exchange-PKN ORLEN, PGNiG (Polskie Górnictwo Naftowe i Gazowe) and KGHM Polska Miedź (where the world's leading enterprises are usually technological companies, the Polish stock exchange is dominated by companies operating in oil, gas and mining industries. Among the top 10 Polish companies listed on the stock exchange in terms of capitalization, there is PKN ORLEN (2020 - 3rd place on the ranking list), valued at PLN 32.5 billion; PGNiG (8th place) valued at PLN 21.2 billion; and KGHM Polska Miedź (9th place), valued at PLN 18.5 billion. In terms of revenue, the top 10 biggest companies are also enterprises belonging to the same sector of the economy-PKN ORLEN (1st place), PGNiG (2nd place), and KGHM Polska Miedź (6th place) [45]). The latest research confirms that the largest Central and Eastern European (CEE) companies have their headquarters in Poland and oil, gas and mining companies are of great significance [46]. Polish companies dominated the ranking of the 500 top companies in the CEE region (TOP 500 CEE) both in terms of the number of 
firms (175 entities) and the turnover achieved in 2018, which exceeded EUR 275 billion. The Polish oil and gas company PKN ORLEN remains the unquestionable leader, and recorded a 15\% increase in turnover. Other Polish oil, gas and mining companies were also high on the list-PGNiG (6th place), PGE (9th place), KGHM Polska Miedź (17th place), Tauron PE (23rd place).

Polish oil, gas and mining companies are also leaders in terms of CSR-according to the XIV Ranking of Responsible Companies in Poland, PKN ORLEN ranks 2nd, PGNiG is in the 5th place and KGHM Polska Miedź occupies the 6th position [47]. The study on the social responsibility of Polish largest companies [8] indicates that $92.2 \%$ of the researched oil, gas and mining companies provide information about the CSR on their websites and follow the CSR principles. All the companies in this sector declared their interest in environmental protection and $92.2 \%$ in human rights. The issue of counteracting corruption was raised by over $60 \%$ of the researched companies and the interest in the supply chain was expressed by almost $80 \%$. Moreover, the firms of this industry issue the greatest number of social reports, almost $82 \%$. Over $69 \%$ of the enterprises have their own codes of ethics. To compare this with other sectors, in the fashion and textile industries, $40 \%$ of the companies declare an interest in sustainable development and $20 \%$ follow the CSR policy, whereas only one company has the code of ethics. In the food industry, although $60 \%$ of the companies take into account the CSR issues on their websites, only $26.6 \%$ pays attention to the supply chains, $40 \%$ have elaborated their CSR policy, only two companies are interested in corruption and one company has a code of ethics.

In order to research the ecologically responsible activities undertaken by the selected Polish leading, gas and mining companies, their CSR reporting was analyzed. For many years, CSR reporting has been an issue in numerous debates and modifications. Obligations and challenges faced by business organizations are constantly changing, and stakeholders care for the data to be reliable and clearly presented. This required the creation of a new method of gathering and presenting extensive documents, including the information about the companies' business activities. The response is integrated reporting, which enables us to present all the necessary information-financial and non-financial (In 2014, the Directive 2014/95/EU amending the Directive 2013/34/EU as regards disclosure of non-financial and diversity information by certain large undertakings and groups entered into force [48]. Consequently, in January 2017, the amended Accounting Act took effect in Poland, which implemented the Directive 2014/95/EU into the Polish law. As a result, since 2018, approximately 300 of the biggest Polish companies are obliged to report on non-financial information. The reports can be an integral part of the company's annual report (integrated report) or a separate document) in the frames of a single document. Hence, in this study, the annual integrated reports published by PKN ORLEN, PGNiG and KGHM from 2014 to 2019 were researched.

ORLEN Group has been publishing integrated reports since 2014 (however, the report for 2014 was dedicated to PKN ORLEN only), in which the company provides detailed information about its policy concerning sustainable growth, including the environmental corporate responsibility [49-54]. The PGNiG Group has been issuing integrated reports since 2017 and the company's previous annual reports include only brief information concerning the initiatives related to environmental protection [55-57]. In turn, KGHM Polska Miedź has been publishing integrated reports since 2013, in which the company presents its CSR activities [58-63].

The selected companies' integrated reports have been investigated with regards to environmental and climate responsibility. The ECSR initiatives undertaken by the analyzed companies have been divided into four categories: water and wastewater management, air emissions, waste management and circular economy and energy management.

In this study, various methods of the analysis will be applied. The theoretical and empirical parts incorporate the exploration of the literature, combined with the review of source materials and companies' reports to carry out a descriptive analysis of the issues 
related to the ECSR. The obtained data are further analyzed with the use of selected statistics to draw conclusions.

\section{Empirical Evidence}

The research was conducted in the form of a case study that covered three Polish companies operating in the oil, gas and mining industries. The presentation and interpretation of the results focuses on the analysis of these firms in a variety of aspects related to the ECSR (the study focuses on the detailed analysis of three companies and may be treated as a case study. This is a different approach to some other studies on the subject, where a multicompany approach is adopted instead of a case study (see, e.g., [64] who examined 170 firms)).

\subsection{Description of the Companies and Their ECSR Strategies}

PKN ORLEN, a Polish oil refiner and petrol retailer, is the largest company in CEE, listed in the global, prestigious rankings, like Fortune Global 500 or Platts Top 250. ORLEN operates in six markets - in Poland, Czechia, Germany, Lithuania, Slovakia and Canada. The company owns modern, integrated assets capable of processing over 35 million tons of various types of crude oil annually and carries out retail sales with the use of the largest CEE network of over 2800 petrol stations. PKN ORLEN offers over 50 top quality petrochemicals and refining products. The company is also a major player in the energy market in Poland and is simultaneously the most important industrial producer of electricity. In the field of mining, it owns a base of oil and gas resources amounting to 197.7 million BOE (in 2019). ORLEN aims at the company's development, which is consistent with global trends, amongst other, in terms of the use of energy sources, technology developments, as well as social processes, which will influence new customer behaviors and expectations. The company focuses on strengthening their market position, customer orientation and the use of an integrated value chain [54].

Since 2019, ORLEN has been implementing its “ORLEN Group's CSR Strategy by 2022", which was created on the basis of the company's internal code of conduct and the 2030 Agenda for Sustainable Development-the UN resolution of 25 September 2015 in global and local dimension. ORLEN's CSR strategy is implemented in five key areas of the CSR: society, environment, employees, customers and business partners. In the frame of the 2030 Agenda, PKN ORLEN is fulfilling the following key goals for the fuel and energy sector: affordable and clean energy; sustainable cities and communities; and additional goals such as (9) industry innovation and infrastructure, (12) responsible consumption and production, (13) climate action, (3) good health and well-being, (1) no poverty, (10) reduced inequality and (4) quality education [54].

In terms of the implementation the company's CSR strategy, it makes investments related to environmental protection. In 2019, the capital expenditure with regard to the environmental protection incurred by the ORLEN Group amounted to EUR 40.5 million (to compare, in 2018 it equaled EUR 124 million), out of which EUR 36.9 million (in 2018EUR 28 million) was spent on investments connected with counteracting pollutions and environmental protection management and EUR 3.6 million (in 2018-EUR 96 million) accounted for the costs of the emission reduction to air and wastewater [53,54] (Table 1). In 2019, ORLEN spent less funds on environmental investments in comparison to the previous year; however, this does not indicate a downward tendency. In 2019, environmental investments were at the same level as the average for the 2015-2017 period (41.2 million EUR). The main initiatives, in 2019, included, e.g., preparatory work for the utilization of used lye from the Płock facility in the context of environmental regulations, construction of Claus and SCOT, the installation for gaseous hydrogen sulfide treatment and the adaptation of fuel gas metering systems for monitoring of $\mathrm{CO}_{2}$ emissions. Environmental investments in 2018 were relatively costly, implying that their aggregated volume peaked to the level of 124 million EUR. In 2018, a number of environmental projects were conducted in PKN ORLEN (e.g., implementation of leakage detection and repair system for refinery 
installations (LDAR), upgrade of the existing vapor recovery installations VRU 3 and VRU 5 at the railway terminal), as well as in PKN ORLEN's distribution facilities and in 16 ORLEN Group companies.

Table 1. Environmental protection related investments, in million EUR, 2014-2019.

\begin{tabular}{lcccccc}
\hline & $\mathbf{2 0 1 4}$ & $\mathbf{2 0 1 5}$ & $\mathbf{2 0 1 6}$ & $\mathbf{2 0 1 7}$ & $\mathbf{2 0 1 8}$ & $\mathbf{2 0 1 9}$ \\
\hline ORLEN & - & 76.8 & 22.0 & 24.8 & 124.0 & 40.5 \\
PGNiG & - & 53.2 & 31.6 & $240.6 / 6.2$ & 309.0 & - \\
KGHM & 140.8 & 148.1 & 230.6 & 88.5 & 33.3 & 53.8 \\
\hline
\end{tabular}

* In the PGNiG Integrated Report for 2017 and 2018 are discrepancies in the amount of money dedicated to environmental investments; according to the report for 2017, it was PLN 26 million (EURO 6.2 million), whereas in the report for 2018, it was PLN 1003.5 million (EUR 240.6 million) -data not provided in the report. Source: own elaboration based on the Integrated Reports by ORLEN, PGNiG and KGHM in 2014-2019 [44-57].

PGNiG (Polskie Górnictwo Naftowe i Gazownictwo Spółka Akcyjna) is the leader of the natural gas market in Poland and one of the largest companies listed on the Warsaw Stock Exchange. The company's business activities comprise the exploration and production of natural gas and crude oil. Through the group's key companies, PGNiG is also active in the area of import, storage, sale and distribution of gas and liquid fuels, as well as heat and electricity generation and distribution. The PGNiG Group diversifies the supplies by developing domestic deposits and sourcing gas from abroad, as one of the largest importers and suppliers of natural gas in Poland. PGNiG has foreign branches and representative offices in Pakistan, the United Arab Emirates, Belgium and Belarus as well as holding equity interests in many companies. It is the sole owner of PGNiG Upstream Norway, engaged in the exploration and exploitation of deposits on the Norwegian Continental Shelf and the Norwegian Sea, as well as PGNiG Supply and Trading selling gas to wholesale customers abroad.

The environmental area of the PGNiG Group is regulated by two key documentsthe QHSE (Quality, Health, Safety, Environment) Policy, demonstrating the company's responsibility for conducting activities considering the global challenges of sustainable development and the PGNiG Group Sustainable Development Strategy for 2017-2022, underlying the significance of the company's environmental dimension as a sustainable business. The company implements three goals of Agenda 2030, such as: 7. affordable and clean energy; 12. responsible consumption and production; 13 . climate action; and 15. life on land [57].

PGNiG is involved in undertaking investments to protect the natural environment. In 2018, the investments related to the environmental protection amounted to EUR 309 million (to compare, it was by EUR 255.8 million more than in 2015 [55-57]) (Table 1).

KGHM Polska Miedź S.A. Goup is a global and innovative organization, which conducts technologically advanced exploration, mining and metallurgical activities. The company is present on four continents: in Europe, South and North America as well as in Asia, globally employing over 34,000 workers. The group's core line of business is the production of copper along with non-ferrous metals accompanying it and the development of resource bases. The company is ranked along the world's top producers of silver and copper. It also produces gold, nickel, rhenium, lead and platinum. The activities of KGHM related to exploration and mining are based on the concessions held by KGHM for the mining of deposits in Poland and the legal titles held by companies belonging to the KGHM International Ltd. Group (Vaughan, ON, Canada) for exploration and extraction of raw materials in the USA, Canada and Chile.

To reduce its impact on the natural environment, KGHM undertakes action in the frame of the European Green Deal. It also implements the recommendations of the Task Force on the Climate-related Financial Disclosures (TCFD) and the EC communication on reporting climate-related information of 20 June 2019 [63]. In 2017, KGHM joined the Partnership for Sustainable Development; the company's undertaken activities are fully 
consistent with the UN sustainable development goals. Based on the 2030 Agenda for Sustainable Development, KGHM has taken action to strengthen the company's positive impact on the achievement of the following goals: 7. affordable and clean energy; 8 . decent work and economic growth; and 9. industry, innovation and infrastructure. Simultaneously, KGHM aims to weaken the negative impact of its operations in terms of other goals, such as: 6 . clean water and sanitation; 13. climate actions; and 15. life on land. The company strives to incorporate the idea of sustainable development at each stage of its value chain, performing tasks from deposit exploration, prospecting and raw material sourcing, through extraction, production, transport and contracts with customers and other stakeholders to waste management and the circular economy to reduce its adverse impact on the environment [63].

In the frames of the implementation of the ECSR, in 2019 KGHM spent approximately EUR 53.8 million on pro-ecological investments, of which the largest expenditure-EUR 10.3 million - was incurred in replacing the absorption and drying towers of the sulphuric acid plant at the Legnica Copper Smelter and Refinery (Table 1). In 2014-2016, KGHM spent more money on environmental initiatives in comparison to the later periods due to, among others, the implementation of a large-scale Pyrometallurgy Modernization Programme at the Głogów I Smelter/Refinery [58-63].

In the following section, particular areas of environmental impact are analyzed. In the case of the improvement of the pro-environmental outcomes, numerous sources can be distinguished; one of them is the increased environmental protection-related investments.

\subsection{Water and Wastewater Management}

ORLEN's main water source is surface water abstracted by the group's largest companies: ANWIL, IKS Solino, PKN ORLEN, ORLEN Południe, ORLEN Lietuva, Unipetrol, Paramo and Spolana, and then distributed through water mains to their own production facilities and other company's installations. According to the integrated reports published by ORLEN in 2014-2019, the group's intake of water was constantly growing in the period analyzed, which depends mainly on the production demands. In 2018-2019, the group's water consumption increased by $4 \%$ due to increased production and the inclusion of new installations to the exploitation [54] (Figure 1).

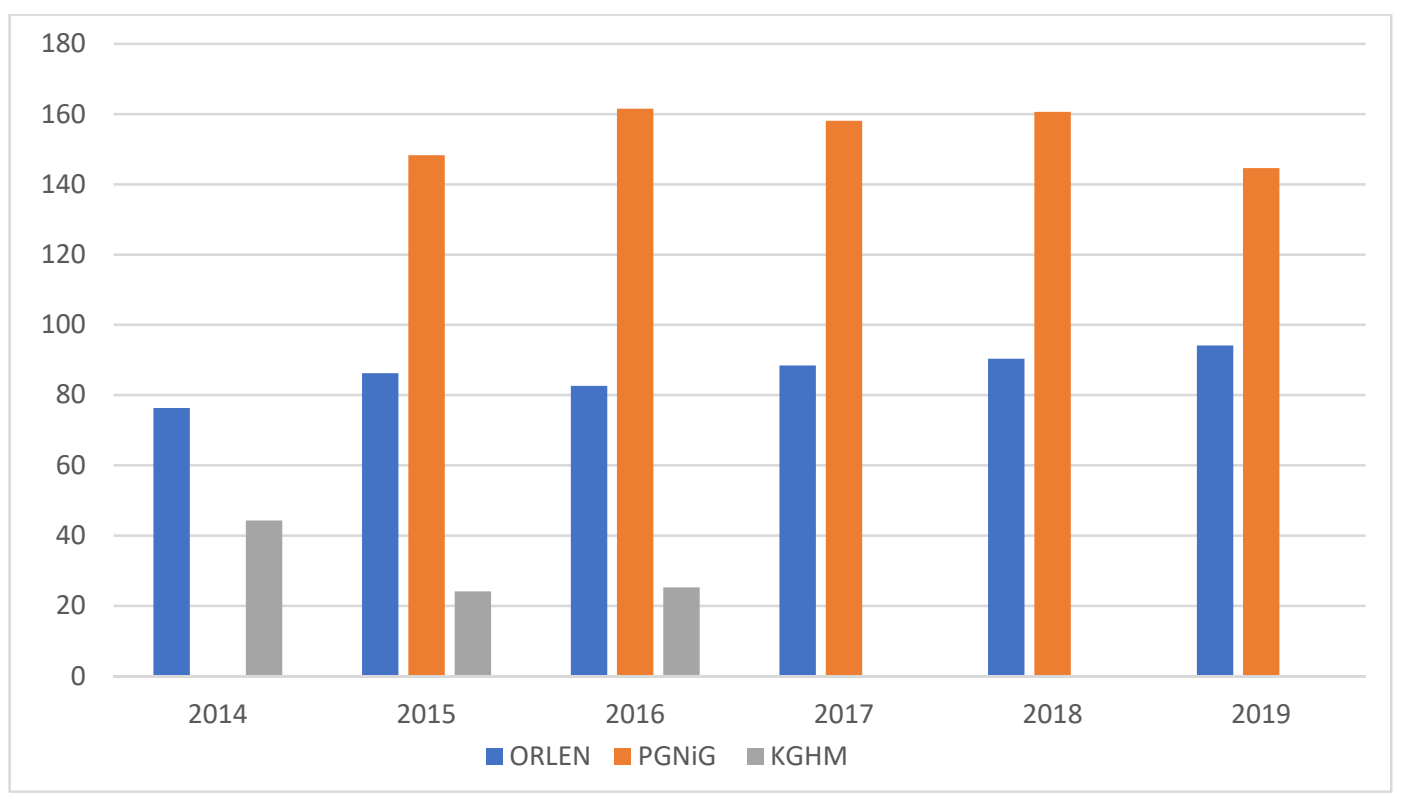

Figure 1. Water consumption (surface, ground and main intakes), in million $\mathrm{m}^{3}$, 2014-2019. Source: same as in Table 1.

Nevertheless, ORLEN takes initiatives to limit the impact on the environment in terms of water consumption. An example is the partial recirculation of water implemented in the 
following units: PKN ORLEN, ORLEN South, ANWIL, Basell Orlen, Polyolefins, ORLEN Lietuva, Paramo, Spolana and Unipetrol, which substantially reduces water withdrawal from the environment. Another action is recovering water from treated effluents and using steam condensate circulation systems and closed water systems for cooling production processes. In 2019, in ORLEN's companies, over 2 billion $\mathrm{m}^{3}$ of water was reused, which accounted for $2145 \%$ of the water consumption, i.e., more that 21 times more than the water volume withdrawn [54].

ORLEN also attempts to reduce the amount of wastewater discharged to the environment (in 2014-2019, it decreased by 6\%-Figure 2) [49-54]. In 2019, it amounted to nearly 51 million $\mathrm{m}^{3}$, out of which industrial wastewater accounted for 44.4 million $\mathrm{m}^{3}(87 \%)$ and other-6.5 million $\mathrm{m}^{3}$. In the wastewater discharged into the environment, sulfates and dissolved inorganic salts have the biggest share of respectively $38 \%$ and $24 \%$. Chlorides account for $16 \%$ of the substance load in wastewater, and dissolved particles, $12 \%$. The share of other substance loads (e.g., sodium, suspended solids) is $10 \%$. In 2019, the substance load in wastewater discharged into the environment amounted to approximately $74,000 \mathrm{Mg}[48]$.

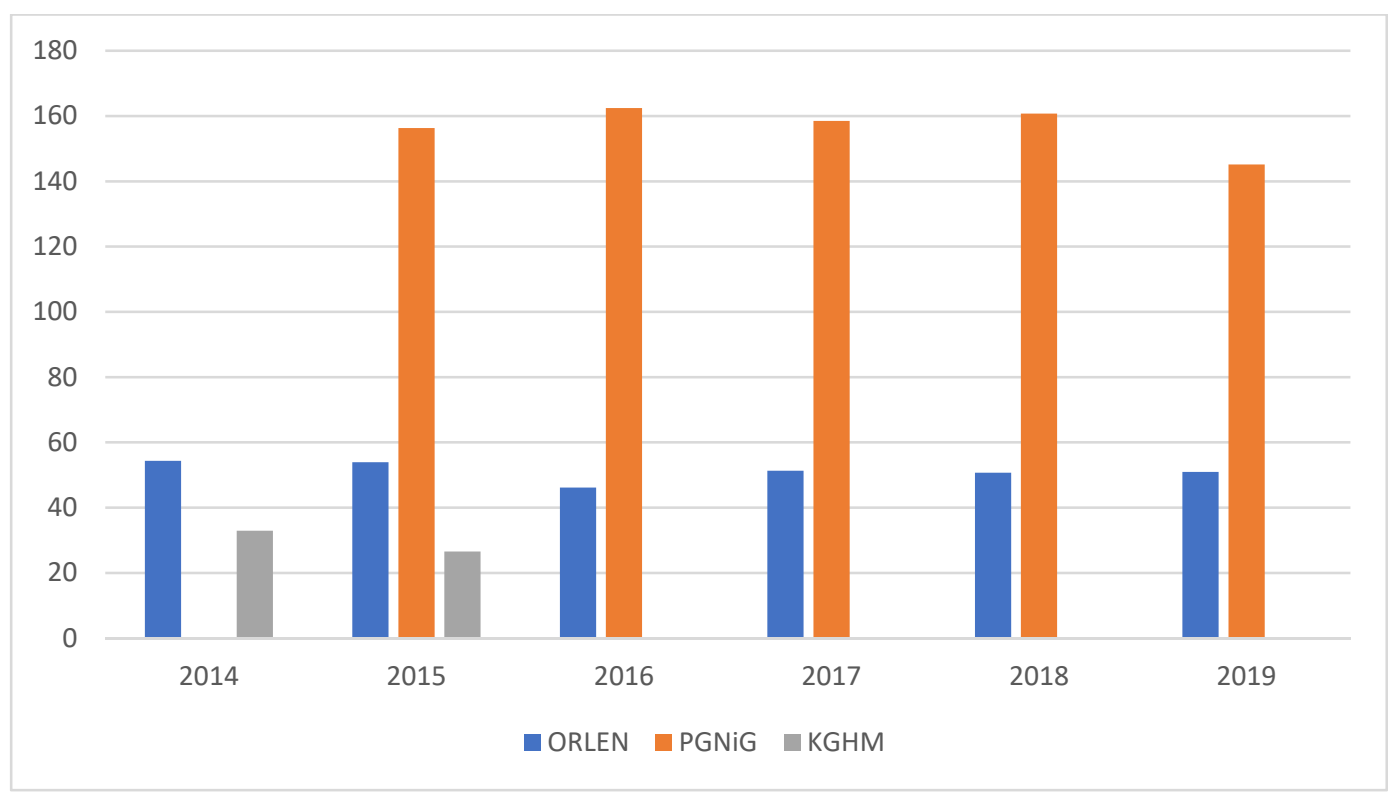

Figure 2. Wastewater discharged to the environment (industrial and other), in million $\left(\mathrm{m}^{3}\right), 2014-2019$. Source: same as in Table 1.

Wastewater from all group's refining companies are directed to the industrial and rainwater sewage systems, and then they are subjected to purification processes. In addition to PKN ORLEN, ANWIL Ship Service, Paramo, Spolana, Unipetrol, ORLEN Lietuva and ORLEN South have their own wastewater treatment facilities. All wastewater reaching the wastewater treatment plants undergo a multi-stage treatment process, and is then discharged into rivers and the Baltic Sea. The remaining companies divert their wastewater streams to sewage systems of other group's companies or external entities.

As a part of PGNiG's exploration and production work, its objectives with regard to the protection of surface and underground water resources are to reduce water consumption

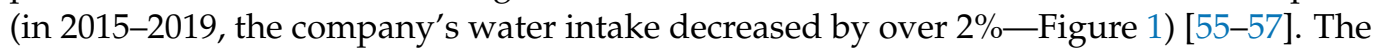
group identifies sources of water supplies and ways of water storage to use water in the most efficient way in a given region. To fulfil this aim, rules for water and wastewater management were introduced, which require monitoring and measuring the volumes of purchased and abstracted water. To reduce waste and water consumption, drilling mud is treated and reused. An example of the reduction in water consumption is reusing some of the industrial wastewater generated in the PGNiG TERMIKA EP units in systems with lower quality requirements [51]. 
As far as the quality of wastewater is concerned, domestic wastewater accounts for $0.27 \%$ of the total water discharge, municipal wastewater $0.07 \%$, industrial $6.08 \%$ and other $93.52 \%$. Wastewater generated by the PGNiG Group is discharged into the sewage system, surface water or soil according to the water permits obtained by the company. The policy of economical water management is followed by the PGNiG TERMIKA Group, which accounts for a large share in the volume of generated wastewater while using water for cooling purposes. This policy is followed during drilling work and, if possible, wastewater is reused to prepare drilling muds. PGNiG TERMIKA EP reuses some of the process wastewater (such as effluents from boiler system blowdowns) in systems with lower quality requirements [57].

KGHM aims at the most effective use of water and closing its circulation in technical, economic and environmental terms (according to the company's integrated reports, it reduced its water consumption and wastewater discharged to the environment by over $43 \%$ in 2014-2016-Figure 1) [58-60]. The initiatives to optimize water and wastewater management serve mainly to limit water consumption in the production processes, especially in concentrators (e.g., Ore Enrichment Plants). Surplus water is discharged to the Oder, constituting an important element of regulation at the level of this river. Additionally, the CuBR Joint Venture has been conducting the project "Innovative technologies of limiting the migration of salt containing underground waters to surface waters in the vicinity of the Żelazny Most Tailings Storage Facility" [63]. The Żelazny Most (Iron Bridge) tailing pond stretched over a $1400-$ hectare area and is surrounded by a 14- $\mathrm{km}$ dam. It is the sole deposition site for flotation tailings from the KGHM's mines and ore-enrichment facilities.

\subsection{Air Emissions}

ORLEN monitors the amount of the air emissions through periodic or continuous measurements; hence, the actual emissions of substances are regularly controlled. The largest share in the total air emissions have $\mathrm{SO}_{2}, \mathrm{NO}_{\mathrm{x}}, \mathrm{CO}$ and particulate matter. In 2014-2019, the ORLEN Group recorded a decrease (by almost 3\%-see Figure 3) in the emission of air pollutants despite the increased processing of crude oil and the inclusion of new installations of ORLEN OIL and ORLEN Asfalt in the structure of the group. It was caused, e.g., by a decrease in the use of oil to the favor of gas fuel and SCR (Selective Catalytic Reduction of nitrogen oxide) installation, as well as better control of combustion parameters and improvement of energy efficiency [54].

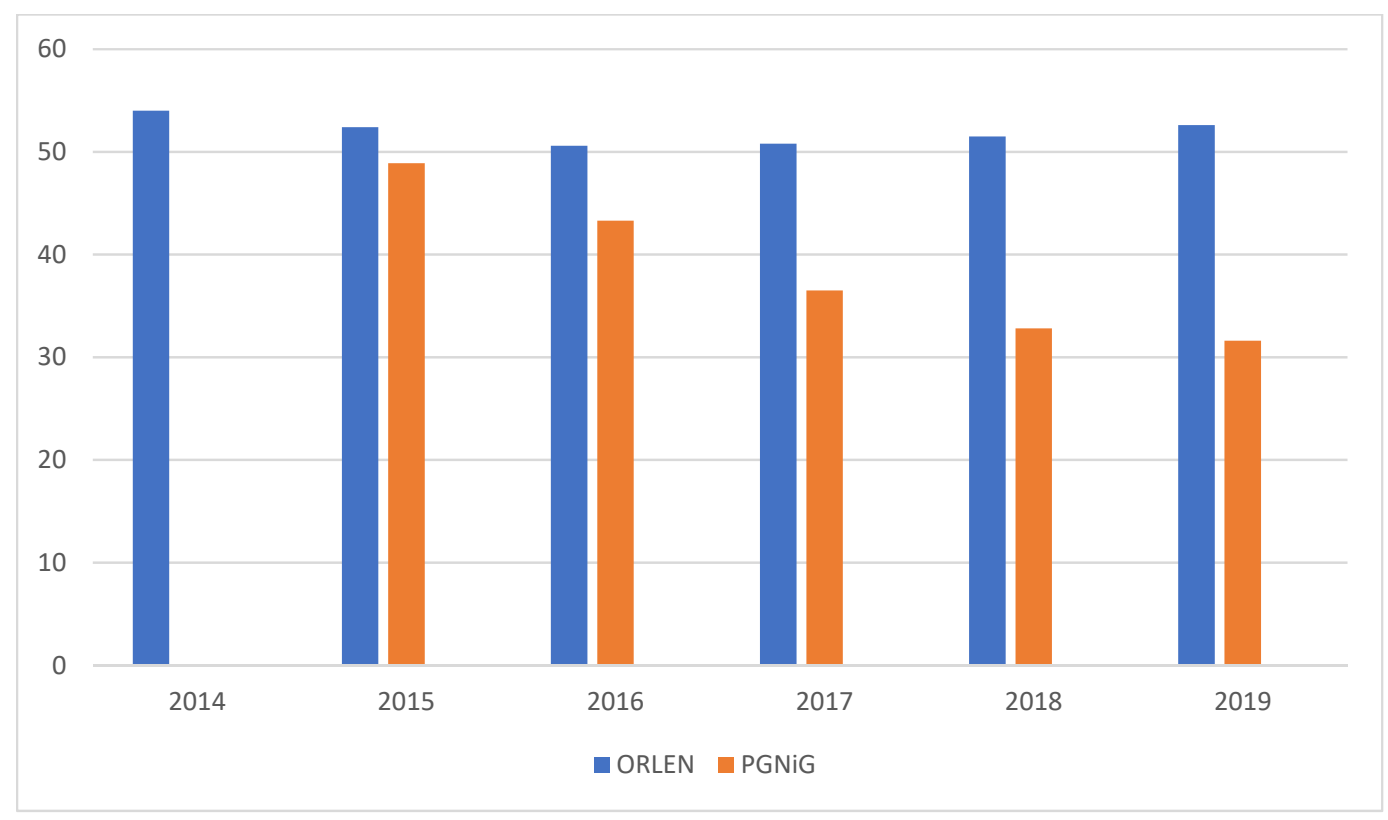

Figure 3. Emissions of air pollutants (e.g., $\mathrm{SO}_{2}, \mathrm{NO}_{\mathrm{x}}, \mathrm{CO}$, particulate matter and other substances), in thousand $\mathrm{Mg}$, 2014-2019. Source: same as in Table 1. 
Emissions are mainly generated by the combustion of fuels to produce electricity and heat as well as in the refining and chemical processes. There are also volatile organic compound emissions and other process-specific emissions. The example of solutions reducing the impact on the environment is the construction of flue gas waste heat recovery equipment at the DEW VI unit at the production plant in Płock. The purpose of the project is to recover $17 \mathrm{GJ}$ of heat that was formerly irretrievably dissipated and to use it for heating up combustion air. The resulting reduction in fuel consumption will cut down the annual $\mathrm{CO}_{2}$ emissions by nearly 8000 tons [54]. The ORLEN Group recorded an increase in emissions in 2016-2019, which was mainly caused by the emission from installations to produce ammonia ANWIL and the annual work of the CCGT installation in Płock [51-54] (Figure 4).

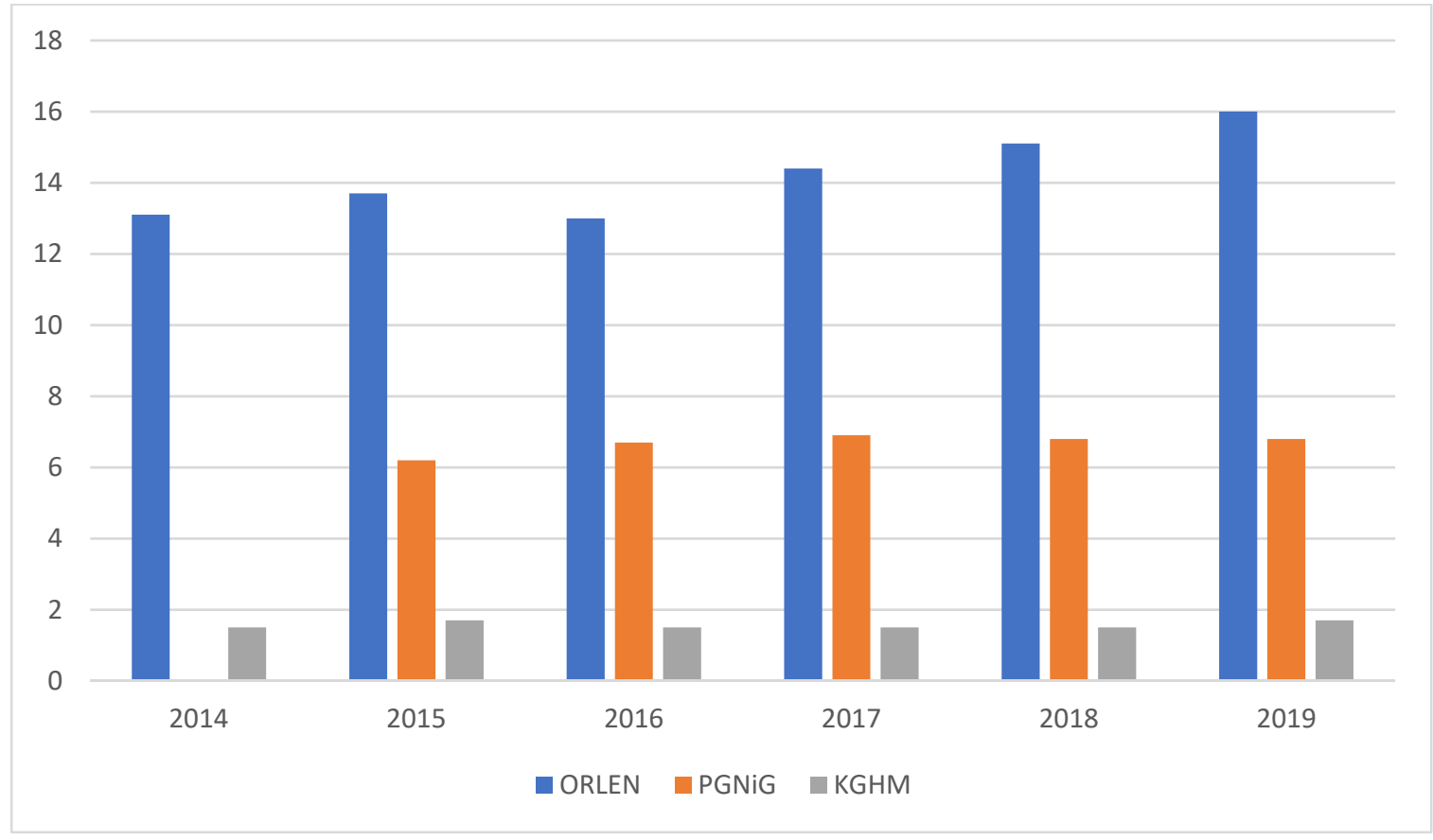

Figure 4. Emissions of $\mathrm{CO}_{2}$ to the air, in million $\mathrm{Mg}$, 2014-2019. Source: same as in Table 1.

In PGNiG, the greenhouse gas emissions are mainly generated from the processes of the energetic combustion of fuels (natural gas, diesel oil, LPG, gasoline) conducted to generate electricity and heat, from the technological processes, such as combustion of the discharge of natural gas (on flare stack, post-combustion of acid gases or storage of crude oil, methanol, LPG) as well as auxiliary processes (e.g., welding, painting, burning of fuels, transport vehicles).

PGNiG has been continuously reducing emissions of pollutants into the air; between 2015 and 2019, the emissions decreased by 35\% [55-57] (Figure 3). From a short-term perspective, the group recorded the stabilization of the total indirect emission of $\mathrm{CO}_{2}$ (Figure 4). The company's methods of reducing the emissions include, among others, using gas as a low-emission fuel, monitoring fuel consumption, reducing the energy intensity of industrial processes and modernizing or replacing the heat sources used for the company's own needs. An example of such initiatives related to the reduction of GHG (greenhouse gases) air emissions is replacing, by PGNiG OD, two central heating boilers with new ones, which will offer considerably higher energy efficiency, lower consumption of gas and reduced $\mathrm{CO}_{2}$ emissions. In turn, the PGNiG Zielona Góra branch has upgraded its gas compressor station and modernized the boiler house, replacing four water boilers with a single modern water boiling unit; consequently, the investment has contributed to the reduction of flue gas emissions. Another initiative continued successfully by Geofizyka Torun (Torun, Poland) is the program of reducing the potential negative impact of machines 
on the environment. It uses seismic survey works ensuring a very good condition of seismic vibrations and reduced air emissions through a gradual upgrade of the company's vehicle fleet (vehicles which were older than 30 were phased out) [57].

KGHM's participation in the European emissions trading system (EST) through the obligation to monitor and report the $\mathrm{CO}_{2}$ emissions and the purchase of emission allowances predisposes the company to seek and implement low-emission solutions. Therefore, KGHM aims at the reduction of the $\mathrm{CO}_{2}$ emissions by changing the shaft furnace technology into the flash furnace. In terms of energy-releasing fuel combustion, it utilizes the low-emission natural gas-fired CCGT (combined-cycle gas turbine) units, and thus partly replaces the fine coal-fired units. With regard to the Best Available Technique (BAT) conclusions or the non-ferrous metal industries, the company has started investment processes in order to adapt installations to the requirements of the conclusions, and thus further reduce the emissions and their impact on the environment [63].

KGHM units pay environmental fees related to environmental impacts; in 2019, they amounted to EUR 4.2 million, out of which the fee of emissions of gases and dusts to the atmosphere equaled over EUR 1.2 million [63]. In addition to environmental fees, KGHM implemented numerous projects and initiatives to reduce the impact on the environment. The example of such undertakings is the advancement of investments involving the need to adapt the metallurgical installations to BAT conclusions, which is related to further reductions in gas and dust emissions, including arsenic emissions. Another example is implementing programmes to promote health and prevent environmental threats, aimed at the people living in the nearest proximity to the company's metallurgical facilities, as well as the construction of the Żelazny Most Tailings Storage Facility.

\subsection{Waste Management and Circular Economy}

Exploration, extraction and processing of raw materials inherently involves the production of hazardous and non-hazardous waste. ORLEN's waste includes mainly waste from the processing of crude oil, the production of organic chemicals and fuel combustion, as well as sludge from treatment of industrial wastewater, waste oil and post-repair waste. The company generated 220.5 thousand Mg of waste in 2019 , which was $44 \%$ more than in 2014 [44-48] (Table 2). The increase in waste (hazardous) was caused, in 2016-2017, by an increase in the processing of crude oil and the production of fuels [51,52]. The increase in waste during 2018-2019 was mainly driven by the production of 41,000 tons of polluted soil with regard to the establishment of new installations [54]. Waste managed by the group in 2019 was subject to recovery and disposal processes at the companies' own units or recovery outside the units. Some of the waste was stored and the remaining volumes were transformed to licensed external operators.

Table 2. Waste production, in thousand Mg, 2014-2019.

\begin{tabular}{ccccccc}
\hline & $\mathbf{2 0 1 4}$ & $\mathbf{2 0 1 5}$ & $\mathbf{2 0 1 6}$ & $\mathbf{2 0 1 7}$ & $\mathbf{2 0 1 8}$ & $\mathbf{2 0 1 9}$ \\
\hline ORLEN & 152.6 & 160.4 & 173.0 & 213.0 & 169.1 & 220.5 \\
PGNiG * & & 762.6 & 674.4 & 690.8 & 610.2 & 807.4 \\
KGHM & $31,066.7$ & $31,350.9$ & & $31,653.2$ & & \\
\hline
\end{tabular}

* Waste includes drilling waste and other waste, excluding municipal waste. Source: same as in Table 1.

To reduce the waste generated, ORLEN established a flue gas desulphurization unit in Płock, which not only helps reduce the emissions of nitrogen and sulphur oxides as well as dusts, but also delivers high quality synthetic gypsum, recognized as a product in its own right; gypsum has been recognized as a by-product and is not classified as waste any longer. ORLEN implements the concept of the circular economy (The European Commission, in March 2020, adopted the new circular economy plan (CEAP), which is one of the main building blocks of the European Green Deal-Europe's Agenda for Sustainable Growth [65]. The amendments of legal regulations following the transposition into the Polish legal framework of Directive (EU) 2018/851 amending Directive 2008/98/EC [66] 
imposed, as of 5 July 2020, certain obligations on Polish companies, including the obligation to adopt the concept of the circular economy as well as to prevent and reduce waste volumes. However, the study [67] indicated that EU companies of the energy sector rarely point to actions related to the circular economy, including activities aimed at the reduction of the $\mathrm{CO} 2$ emissions, as those treated with high priority) in the group's waste management approach. An example of such a solution is the operation of a specialist hydrogenation line by ORLEN Południe, which enables the safe regeneration of waste oils into base oils used to make lubricating oils [54].

PGNiG optimizes the volume of generated waste by implementing new technologies, using eco-friendly materials and products as well as organizing waste sorting awareness programs. For example, in 2019, PGNiG GHPB appointed a technical team to develop a technology for reducing drilling waste volumes by recovering and reusing the waste. The branch in Zielona Góra conducted internal inspections to assess compliance with environmental protection regulations regarding, amongst others, the management and storage of hazardous substances, selective waste collection and emergency planning. In turn, PGNiG TERMIKA EP reduces the output of waste by using fuels of the highest quality and maintaining optimum conditions in its processes. However, despite the fact that all companies of the PGNiG Group, in 2019, aimed at optimizing the amount of waste generated, it increased by $32 \%$ in comparison with the previous year [57].

To implement the concept of the circular economy, the PGNiG Group took actions to meet the regulatory requirements by managing waste and treating it as recyclable. An example of such activities is the initiative implemented by PGNiG TERMIKA; it produces, annually, approximately 550-650 thousand tons of ash, slag and gypsum, substances known as combustion by-products and treated as valuable materials that may be reused in other industrial sectors. Since these substances are considered not to be harmful to human health or the natural environment, they may be reused in different material or product applications, e.g., in the building materials industry. Another example in line with the principles of the circular economy was the reclamation of the Żeran CHP ash landfill site, initiated in 2006. In the project, the employed method of site grading, including the use of slags as a sub-base of the Maria Curie-Skłodowska Bridge in Warsaw, was of particular significance. Thus, a solution was applied in which a substance considered to be waste in one sector of the economy was used as an important resource in another one, creating both a reduction in the cost of all projects involved and establishing safe valuable mineral deposits [57].

KGHM generates over 31 thousand Mg of waste annually (Table 2); therefore, waste management and the implementation of the circular economy concept is one of the major directions of the company's pro-environment activities. The example of the largest investment project aimed at implementing the circular economy concept was the start-up of the Revolving Casting-Refining furnace for recycling the smelting of copper. The furnace fulfils the highest environmental protection standards and is equipped with the latest process gas treatment installation. The investment will substantially increase the use of recycled copper in the KGHM company. Another investment project in terms of the circular economy concept is the manner of conducting the extension of the Żelazny Most Tailings Storage Facility to increase dam height without acquiring additional land. It will serve as both a tailings storage facility and a future economy reservoir. The investment supporting the ecological effectiveness of storing there the flotation waste was the establishment of the Tailings Segregation and Thickening Station. The investment assumes that the implementation of the compaction technology for the tailings remains after the completed ore enrichment process, which will result in a reduction of the water circulating between the Ore Enrichment Plants and the smelting plants, consequently leading to increased safety at the Żelazny Most facility. Additionally, it will give the possibility to deposit the whole stream of waste within a smaller area, to improve stability of the Żelazny Most facility due to the smaller quantity of water and to eliminate a substantial part of water circulating between the KGHM units [63]. 


\subsection{Energy Management}

Currently, ORLEN is Poland's largest industrial electricity producer and fourth largest electricity producer in Poland, with an output sufficient to meet the demand of the Group's own plants and external customers. By acquiring, in April 2020, the Energa Group, PKN ORLEN will gain a large distribution network spanning northern and central Poland, as well as a substantial renewable portfolio, significant to its planned offshore wind farm projects [54]. ORLEN is particularly focused on continuous work on the operational excellence in the fields, such as optimalization of production processes, distribution losses and an improved efficiency of process units.

The energy consumed by the majority of the PGNiG Group was mostly energy generated internally from non-renewable sources (other members of the group have signed contracts with energy companies). In 2019, the installation one of PGNiG TERMIKA EP undertook activities to reduce electricity consumption for its own needs by optimizing the location where energy-intensive equipment operates and by minimizing the time of operations under non-standard conditions. Additionally, technological processes maintaining appropriate technological parameters and optimizing energy consumption were automated. In turn, PTER (PGNiG TERMIKA Energetyka Rozproszona) supports the promotion of energy cluster projects and the development of local energy markets based on local resources. The company cooperates with PGNiG OD in carrying out, developing and promoting projects as part of the program to eliminate low-stack emissions [57].

The primary objective of KGHM regarding energy management is to implement a rational energy management program while ensuring the security of an energy supply to the facilities and installations of the company's core production line. The company is committed to provide the resources necessary to achieve the planned energy objectives and outcomes, conduct activities in compliance with legal regulations and requirements related to the consumption of energy. KGHM also aims at creating desirable attitudes, build awareness and constantly improve the skills of the employees. Additionally, the company focuses on preventing waste in the area of energy consumption, as well as cooperating with partners and suppliers in the procurement of goods and services, taking into account the energy efficiency as an important criterion of the selection [58-63].

KGHM has been conducting activities to improve the energy efficiency by increasing the share of energy obtained from the renewable sources and owned by the company. To that end, the Lubin mine, which consumes the greatest amount of heat in the whole heat stream consumed by the company, has begun a program of heat recovery from mining waters by using heat pumps [63].

\section{Discussion}

Tables 3 and 4 recapitalize the earlier analysis. They present the structure of the environmental impact of particular categories (water consumption, wastewater, $\mathrm{CO}_{2}$ emissions, waste) in a comparable way (See [68] for a different approach showing the environmental impact of water use, carbon emissions and other emission types). Table 3 shows the statistics related to the total revenue of the companies. Total revenue may be treated as the proxy of the size of the company as it indicates the value of the output produced by a given company. In such a case we can directly compare the environmental impact of the analyzed companies and the conclusions are not biased due to the fact that larger companies pollute more.

As can be seen from Table 3, the activities of ORLEN, PGNiG and KGHM affect the environment in a diversified way. As regards water consumption, the leaders are KGHM and ORLEN whose water consumption amount to 1.51 and 1.20 million $\mathrm{m}^{3}$ per billion PLN of total revenue, respectively. The outcomes of PGNiG indicate much lower consumption. This trend results from the fact that the processing of crude oil and the extraction of copper in mines are more water-consuming than the extraction of gas and crude oil-using pipes. The similar results are recorded for wastewater for the same reasons. In the case of $\mathrm{CO}_{2}$ emissions, it is ORLEN that pollutes the environment the most. These outcomes reflect 
the physical character of the production process and they are unlikely to be substantially changed in the future. For example, in an oil refinery plant in Płock belonging to ORLEN, there are a number of installations that pollute the environment, which are not seen in the case of crude oil, gas and copper extraction. However, copper extraction contributes to the production of huge amounts of waste, which is the result of extracting copper from underground sources and the necessity to separate copper from the other minerals (1515.50 for KGHM vs. 2.60 and 1.88 for ORLEN and PGNiG).

Table 3. Structure of the environmental impact (period average).

\begin{tabular}{|c|c|c|c|}
\hline Specification & ORLEN 2015-2019 & PGNiG 2015-2019 & KGHM * 2016-2019 \\
\hline total revenue (in million PLN) & 72,031 & 37,755 & 20,691 \\
\hline water consumption (in million $\mathrm{m}^{3}$ ) & 86.3 & 154.6 & 31.2 \\
\hline wastewater (in million $\mathrm{m}^{3}$ ) & 50.6 & 156.6 & 29.7 \\
\hline $\mathrm{CO}_{2}$ emissions (in million $\mathrm{Mg}$ ) & 14.4 & 6.7 & 1.6 \\
\hline waste (in thousand $\mathrm{Mg}$ ) & 187.2 & 709.1 & $31,356.9$ \\
\hline water consumption (per billion PLN of total revenue) & 1.20 & 0.41 & 1.51 \\
\hline wastewater (per billion PLN of total revenue) & 0.70 & 0.41 & 1.44 \\
\hline $\mathrm{CO}_{2}$ emissions (per billion PLN of total revenue) & 0.20 & 0.02 & 0.08 \\
\hline waste (per billion PLN of total revenue) & 2.60 & 1.88 & 1515.50 \\
\hline
\end{tabular}

* Data concerning water consumption are for 2014-2016; wastewater-2014-2015; waste-2014-2017. Source: own elaboration based on reports and websites of the selected companies [69-71].

Table 4. Structure of environmental impact (dynamics).

\begin{tabular}{cccc}
\hline & ORLEN 2015-2019 & PGNiG 2015-2019 & KGHM ** 2016-2019 \\
\hline dynamics of output * (\% change) & 9.2 & -5.7 & 4.5 \\
water consumption (\% change) & 9.2 & -2.5 & -43.1 \\
wastewater (\% change) & -5.6 & -7.2 & -19.5 \\
CO 2 emissions (\% change) & 16.8 & 9.7 & 13.3 \\
waste (\% change) & 37.5 & 5.9 & 1.9 \\
\hline
\end{tabular}

* ORLEN—production of petrol, LPG, diesel fuels, fertilizers, etc.; PGNiG—crude oil and gas production (domestic and foreign); KGHMcopper production. ** Data concerning water consumption are for 2014-2016; wastewater-2014-2015; waste-2014-2017. Source: same as in Table 3.

Table 4 presents the environmental impact of particular categories compared to the output volumes of the selected companies. In ORLEN, water consumption, as well as the amount of wastewater discharged to the environment, $\mathrm{CO}_{2}$ emissions and the amount of produced waste have increased more significantly than in PGNiG and KGHM. However, it should be emphasized that ORLEN is also the company that recorded the highest increase in output (by 9.2\%) in 2015-2019. In turn, PGNiG reduced the water consumption, the amount of wastewater and $\mathrm{CO}_{2}$ emissions in the researched period, but the company's output decreased as well (by $5.7 \%$ ). In the case of KGHM, a growth in the output (by $4.5 \%$ ) was accompanied by a fall in water consumption and wastewater. All three companies recorded an increase in $\mathrm{CO}_{2}$ emissions and waste; however, they managed to reduce the amount of wastewater discharged to the environment.

\section{Conclusions}

The analyzed Polish companies of the oil, gas and mining sectors report their engagement in the ECSR. They use a number of the tools of the ECSR implementation, such as environmental reporting, reduction of emissions of waste, pollutions and greenhouse gases, as well as environmentally responsible initiatives. They implement the principles of the circular economy, as opposed to the linear economy, and they assume the maintenance of products, materials and resources in the economy as long as this is possible, while reducing the amount of the waste. 
ORLEN, PGNiG and KGHM undertake pro-environmental initiatives and implement pro-environmental projects. The most important fields of action conducted by the analyzed companies in terms of the environmental protection are as follows:

- identification, supervision and monitoring of environmental issues;

- application of environmentally friendly technologies and techniques to reduce the negative environmental footprint;

- $\quad$ reducing the emissions of greenhouse gases (decarbonization);

- regularly monitoring and reporting the outcomes of the environmental activities, including the use of natural resources, the level of emissions and waste;

- $\quad$ aiming at the achievement of the maximal ecological neutrality, including the use of water;

- $\quad$ increasing the involvement in the area of the closed circle economy, the development of distributing infrastructure for alternative fuels (e.g., electrical energy, biofuels and hydrogen);

- $\quad$ conducting and participation in R \& D projects in terms of new technologies;

- identification and fulfilment of legal requirements and other regulations, undertaking remediation and reclamation measures.

Despite the fact that the researched Polish companies-ORLEN, PGNiG and KGHMare engaged in numerous pro-ecological initiatives and projects, they exert a diverse impact on the natural environment, which results from the different character of their conducted core businesses. KGHM and ORLEN's main activities require a greater consumption of water than PGNiG's production and extraction processes, which, in turn, leads to the greater discharge of wastewater into the environment. Similarly, the relatively high emissions of $\mathrm{CO}_{2}$ into the air by ORLEN are also connected to the nature of their core activities, whereas the character of extraction processes conducted by KGHM contributes to the relatively high production of waste. Despite ORLEN's declaration to follow the principles of ECSR and the implementation of environmentally friendly initiatives and projects, it recorded the highest increase in water consumption, $\mathrm{CO}_{2}$ emissions and waste production. However, this does not mean that the company does not manage the environmental area in a responsible way, supporting the rational management of the resources. Their increased (in the researched period) footprint on the environment partially results from a growth in the output volume. All the researched companies managed to reduce their environmental impact in terms of the amount of wastewater discharged to the environment. KGHM also succeeded in decreasing the amount of water the company uses in its production and extraction processes. Nevertheless, carbon emission and waste management still remain the areas that need improvement.

Funding: This research received no external funding.

Institutional Review Board Statement: Not applicable.

Informed Consent Statement: Not applicable.

Data Availability Statement: Data are taken from publicly available websites of the analyzed companies and not from databases.

Conflicts of Interest: The author declares no conflict of interest.

\section{References}

1. Frederick, W. The growing concern over social responsibility. Calif. Manag. Rev. 1960, 2, 54-61. [CrossRef]

2. McGuire, J. Business and Society; McGraw-Hill: New York, NY, USA, 1963.

3. Donaldson, T. Corporations and Morality; Prentice Hall: Englewood Cliffs, NJ, USA, 1982.

4. Langtry, B. Stakeholders and the moral responsibilities of business. Bus. Ethics Q. 1994, 4, 431-443. [CrossRef]

5. Lulewicz-Sas, A.; Godlewska, J. Assessment of environmental issues of Corporate Social Responsibility by enterprises in Poland-Results of empirical research. Procedia Soc. Behav. Sci. 2015, 213, 533-538. [CrossRef] 
6. Suska, M. Corporate Social Responsibility in Asia: Asian vision vs. American vision. In Azjatyckie Systemy Ochrony Praw Człowieka: Inspiracja Uniwersalna_Uwarunkowania Kulturowe-Bariery Realizacyjne; Jaskiernia, J., Spryszak, K., Eds.; Adam Marszałek: Torun, Poland, 2016; pp. 220-244.

7. Suska, M. Corporate social responsibility (CSR)—the human rights regime in Africa. In Ochrona Praw Człowieka w Afryce: Aksjologia-Instytucje—Nowe Wyzwania_Praktyka; Jaskiernia, J., Spryszak, K., Eds.; Adam Marszałek: Torun, Poland, 2017; pp. 103-121.

8. Piskalski, G. Społeczna Odpowiedzialność Biznesu w Polskich Realiach. Teoria a Praktyka; Fundacja CentrumCSR.pl: Warszawa, Poland, 2015.

9. Cameron, P.D.; Stanley, M.C. Oil, Gas and Mining; A Sourcebook for Understanding the Extractive Industries; World Bank: Washington, DC, USA, 2017.

10. Spector, B. Business responsibilities in a divided world: The Cold War roots of the corporate social responsibility movement. Enterp. Soc. 2008, 9, 314-336. [CrossRef]

11. Bowen, H. Social Responsibilities of the Businessman; Harper \& Row: New York, NY, USA, 1953.

12. Davis, K. Can business afford to ignore social responsibilities? Calif. Manag. Rev. 1960, 2, 70-76. [CrossRef]

13. Walton, C. Corporate Social Responsibilities; Wadsworth: Belmont, CA, USA, 1967.

14. Carroll, A. Corporate social responsibility: Will industry respond to cut-backs in social program funding. Vital Speeches Day 1983, $49,604-608$.

15. Carroll, A. Corporate social responsibility: Evolution of a definitional construct. Bus. Soc. 1999, 38, 268-295. [CrossRef]

16. Carroll, A. The pyramid of corporate social responsibility: Toward the moral management of organizational stakeholders. Bus. Horiz. 1999, 34, 39-48. [CrossRef]

17. Carroll, A.; Shabana, K. The business case for corporate social responsibility: A review of concepts, research and practice. Int. J. Manag. Rev. 2010, 12, 85-105. [CrossRef]

18. Frederick, W. Corporate social responsibility: Deep roots, flourishing growth, promising future. In The Oxford Handbook of Corporate Social Responsibility; Crane, A., Matten, D., McWilliams, A., Moon, J., Siegel, D., Eds.; Oxford University Press: New York, NY, USA, 2008; pp. 522-531.

19. Waddock, S.A.; Graves, S.B. The corporate social performance-financial performance link. Strateg. Manag. J. 1997, 18, 303-319. [CrossRef]

20. Margolis, J.D.; Walsh, J.P. People and Profits? The Search for a Link between the Company's Social and Financial Performance; Lawrence Erlbraum Associates: Mahwah, NJ, USA, 2001.

21. Orlitzky, M.; Schmidt, F.L.; Rynes, S.L. Corporate social and financial performance: A meta-analysis. Organ. Stud. 2003, 24, 430-441. [CrossRef]

22. Aguilera, R.V.; Rupp, D.E.; Williams, C.A.; Ganapathi, J. Putting the S back in corporate social responsibility: A multilevel theory of social change in organizations. Acad. Manag. Rev. 2007, 32, 836-863. [CrossRef]

23. European Commission. Communication from the Commission to the European Parliament, the Council, the European Economic and Social Commitee and the Commitee of the Regions; European Commission: Brussels, Belgium, 2011; p. 681.

24. Ambec, S.; Lanoie, P. Does it pay to be green? A systematic overview. Acad. Manag. Exec. 2008, 22, 45-56.

25. Goldman Sachs. 2008 Environmental Report; Goldman Sachs: New York, NY, USA, 2008.

26. International Civil Aviation Organisation. 2019 Environmental Report; International Civil Aviation Organisation: Montreal, Canada, 2019.

27. Laroche, M.; Bergeron, J.; Barbaro-Forleo, G. Targeting consumers who are willing to pay more for environmentally friendly products. J. Consum. Mark. 2001, 18, 503-520. [CrossRef]

28. Jansson, J.; Marell, A.; Annika, N. Green consumer behavior: Determinants of curtailment and eco-innovation adoption. J. Consum. Mark. 2010, 27, 358-370. [CrossRef]

29. Huong Tran, T.T.; Paparoidamis, N.G. Eco-innovations in global markets: The effect of ecological (in)congruence on consumers' adoption intentions. J. Int. Market. 2020, 28, 64-83. [CrossRef]

30. Stronza, A.; Gordillo, J. Community views of ecotourism. Ann. Tour. Res. 2008, 35, 448-468. [CrossRef]

31. Chiutsi, S.; Mukoroverwa, M.; Karigambe, P.; Mudzengi, B.K. The theory and practice of ecotourism in Southern Africa. J. Hosp. Manag. Tour. 2011, 2, 14-21.

32. Wells, V.K.; Manika, D.; Gregory-Smith, D.; Taheri, B.; McCowen, C. Heritage tourism, CSR and the role of employee environmental behaviour. Tour. Manag. 2015, 48, 399-413. [CrossRef]

33. Nik Ramli Nik, R.; Naja, M. Spill over of environmentally friendly behaviour phenomenon: The mediating effect of employee organizational identification. OIDA Int. J. Sustain. Dev. 2011, 2, $29-42$.

34. Islam, T.; Ali, G.; Asad, H. Environmental CSR and pro-environmental behaviors to reduce environmental dilapidation: The moderating role of empathy. Manag. Res. Rev. 2019, 42, 332-351. [CrossRef]

35. Lyon, T.P.; Maxwell, J.W. Corporate social responsibilty and the environment: A thereotical perspective. Rev. Environ. Econ. Policy 2008, 2, 240-260. [CrossRef]

36. Babiak, K.; Trendafilova, S. CSR and environmental responsibility: Motives and pressures to adopt green management practices. Corp. Soc. Responsib. Environ. Manag. 2011, 18, 11-24. [CrossRef] 
37. Rahman, N.; Post, C. Measurement issues in environmental corporate social responsibility (ECSR): Toward a transparent, reliable and construct valid instrument. J. Bus. Ethics 2012, 105, 307-319. [CrossRef]

38. Khojastehpour, M.; Johns, R. The effect of environmental CSR issues on corporate/brand reputation and corporate profitability. Eur. Bus. Rev. 2014, 26, 330-339. [CrossRef]

39. Nik Ramli Nik, R.; Nor Irwani, A.R.; Shaiful Annuar, K. Environmental corporate social responsibility (ECSR) as a strategic marketing initiatives. Procedia Soc. Behav. Sci. 2014, 130, 499-508.

40. Li, J.Y.; Overton, H.; Bhalla, N. Communicative action and supportive behaviors for environmental CSR practices: An attitudebased segmentation approach. Corp. Commun. Int. J. 2020, 25, 171-186. [CrossRef]

41. Guenther, E.; Hoppe, H.; Poser, C. Environmental corporate social responsibility of firms in the mining and oil and gas industries: Current status quo of reporting following GRI Guidelines. Greener Manag. Int. 2006, 53, 7-25.

42. Frynas, J.G. Corporate social responsibility in the oil and gas sector. J. World Energy Law Bus. 2009, 2, 178-195. [CrossRef]

43. Shvarts, E.; Pakhalov, A.; Knizhnikov, A. Assessment of environmental responsibility of oil and gas companies in Russia; the rating method. J. Clean. Prod. 2016, 127, 143-151. [CrossRef]

44. Koolwal, N.; Khandelwal, S. Corporate social responsibility (CSR) implementation in oil \& gas industry: Challenges and solutions. In Proceedings of the International Conference on Sustainable Computing in Science, Technology and Management (SUSCOM), Amity University Rajasthan, Jaipur, India, 26-28 February 2019; Available online: https:/ / ssrn.com/abstract=3358059 (accessed on 20 April 2021).

45. Największe Firmy w Polsce, Największe Firmy na Świecie. Available online: https://lepiejnizwbanku.pl/ogolna/najwiekszefirmy-w-polsce-najwieksze-firmy-na-swiecie/ (accessed on 20 April 2021).

46. Business Alert. Polskie Społki Paliwowo, Energetyczne i Górnicze w Ranking TOP 500 CEE. 06.09.2019. Available online: https: // biznesalert.pl/polskie-spolki-paliwowe-energetyczne-i-gornicze-w-rankingu-top-500-cee/ (accessed on 20 April 2021).

47. Forum Odpowiedzialnego Biznesu. Partnerzy Strategiczni FOB Liderami XVI Rankingu Odpowiedzialnych Firm. 04.06.2020. Available online: http:/ / odpowiedzialnybiznes.pl/aktualności/partnerzy-strategiczni-fob-liderami-xiv-rankinguodpowiedzialnych-firm/ (accessed on 20 April 2021).

48. Official Journal of the European Union. Directive 2013/34/EU of the European Parliament and of the Council of 22 October 2014. 2014. Available online: https: / / eur-lex.europa.eu/legal-content/EN/TXT/PDF/?uri=CELEX:32014L0095\&from=FI (accessed on 30 March 2021).

49. PKN ORLEN. Napędzamy Przyszłość, Raport Zintegrowany 2014. Available online: https://www.orlen.pl/PL/RelacjeInwestorskie/ Raportyroczne/Strony/default.aspx (accessed on 25 March 2021).

50. ORLEN. Raport zintegrowany Grupy ORLEN 2015. Available online: https://www.orlen.pl/PL/RelacjeInwestorskie/ Raportyroczne/Strony/default.aspx (accessed on 25 March 2021).

51. ORLEN. Raport zintegrowany Grupy ORLEN 2016. Available online: https://www.orlen.pl/PL/RelacjeInwestorskie/ Raportyroczne/Strony/default.aspx (accessed on 25 March 2021).

52. ORLEN. Raport zintegrowany Grupy ORLEN 2017. Available online: https://www.orlen.pl/PL/RelacjeInwestorskie/ Raportyroczne/Strony/default.aspx (accessed on 25 March 2021).

53. ORLEN. Raport zintegrowany Grupy ORLEN 2018. Available online: https://www.orlen.pl/PL/RelacjeInwestorskie/ Raportyroczne/Strony/default.aspx (accessed on 25 March 2021).

54. ORLEN. Raport zintegrowany Grupy ORLEN 2019. Available online: https://www.orlen.pl/PL/RelacjeInwestorskie/ Raportyroczne/Strony/default.aspx (accessed on 25 March 2021).

55. PGNiG. Raport Zintegrowany 2017. Available online: https://pgnig.pl/relacje-inwestorskie/prezentacje-i-materialy/raportyroczne (accessed on 27 March 2021).

56. PGNiG. Raport Zintegrowany 2018. Available online: https://pgnig.pl/relacje-inwestorskie/prezentacje-i-materialy/raportyroczne (accessed on 27 March 2021).

57. PGNiG. Raport Zintegrowany 2019. Available online: https://pgnig.pl/relacje-inwestorskie/prezentacje-i-materialy/raportyroczne (accessed on 27 March 2021).

58. KGHM. Raport Zintegrowany 2014. Available online: https://kghm.com/pl/inwestorzy/centrum-wynikow/raportyzintegrowane (accessed on 28 March 2021).

59. KGHM. Raport Zintegrowany 2015. Available online: https://kghm.com/pl/inwestorzy/centrum-wynikow/raportyzintegrowane (accessed on 28 March 2021).

60. KGHM. Raport Zintegrowany 2016. Available online: https://kghm.com/pl/inwestorzy/centrum-wynikow/raportyzintegrowane (accessed on 28 March 2021).

61. KGHM. Raport Zintegrowany 2017. Available online: https://kghm.com/pl/inwestorzy/centrum-wynikow/raportyzintegrowane (accessed on 28 March 2021).

62. KGHM. Raport Zintegrowany 2018. Available online: https://kghm.com/pl/inwestorzy/centrum-wynikow/raportyzintegrowane (accessed on 28 March 2021).

63. KGHM. Raport Zintegrowany 2019. Available online: https://kghm.com/pl/inwestorzy/centrum-wynikow/raportyzintegrowane (accessed on 28 March 2021).

64. Ehsan, S.; Nazir, M.S.; Nurunnabi, M.; Raza Khan, Q.; Tahir, S.; Ahmed, I. A multimethod approach to assess and measure Corporate Social Responsibility disclosure and practices in a developing economy. Sustainability 2018, 10, 2955. [CrossRef] 
65. European Commission. Circular Economy Action Plan. For a Cleaner and More Competitive Europe. Available online: https:/ / ec.europa.eu/environment/circular-economy/pdf/new_circular_economy_action_plan.pdf (accessed on 20 April 2021).

66. Official Journal of the European Union. Directive (EU) 2018/851 of the European Parliament and the Council of 30 May 2018 Amending Directive 2008/98/EC on Waste L. Available online: https:/ / eur-lex.europa.eu/legal-content/EN/TXT/PDF/?uri=CELEX:32018L0 851\&rid $=5$ (accessed on 30 March 2021).

67. Janik, A.; Ryszko, A.; Szafraniec, M. Greenhouse gases and circular economy issues in sustainability reports from the energy sector in the European Union. Energies 2020, 13, 5993. [CrossRef]

68. Freiberg, D.; Park, D.G.; Serafeim, G.; Zochowski, T.R. Corporate Environmental Impact: Measurement, Data and Information. Working Paper 20-098; Harvard Business School: Boston, MA, USA, 2021.

69. ORLEN. ORLEN w Liczbach 2019. Available online: https://www.orlen.pl/PL/RelacjeInwestorskie/InformacjeFinansowe/ Strony/OrlenWLiczbach.aspx (accessed on 18 May 2021).

70. PGNiG. Polakie Górnictwo Naftowe i Gazownictwo SA, Maj 2019. Available online: https://pgnig.pl/documents/10184/258077 0/Company-Overview_PL_May2019.pdf/5da1eb13-8aaf-47ef-93b2-a8a18a6aae5c (accessed on 18 May 2021).

71. KGHM. Raporty Zintegrowane. Available online: https://kghm.com/pl/inwestorzy/centrum-wynikow (accessed on 18 May 2021). 